\title{
2 The (im)possibilities of transgression, or, reflections on the awkward relation between Strathern and queer politics
}

Irene Peano ${ }^{1}$

Abstract: Marilyn Strathern's body of work is here analysed in its 'partial connections' to queer thinking, from an inescapably political dimension. The chapter engages in a work of reassemblage, making Strathern's reflections compatible with those of Judith Butler and therefore also pointing to, and working through, their incomparabilities and limits. It is an exercise in cyborg-making, which draws on Strathern's engagement with the work of Donna Haraway, operated by assembling two of Strathern's terrains of inquiry in dialogue to queer thinking: institutional and disciplinary practices, on the one hand, and the awkward relations between feminist/Marxist theories and anthropological description, on the other. Here, issues of transgression and its aporias, and the necessarily relational character of identification, are interrogated for how they can guide the development of an insurgent mode of knowledge production which is founded on risk, vulnerability and the conscious search for a future that is already present in abject form. This, it is argued, cannot but mean dealing with politics in the ruins of university disciplines and institutions.

Marilyn Strathern: ... what is it then that I substitute for religion that might have the same effect on my intellectual life? I think I would say an interest and love of institutions. ${ }^{2}$ [...] I suspect that those aspects of religion that inspire social scientists are indeed those aspects to do with the ecclesiastical organization of religious life, as it were, regardless of what belief systems are involved. And if you were to look for a counterpart of that in my own life I would say that I have always liked being in contexts where there was organized life around me. I like being in hospital, for example, find that very relaxing - it depends on what one's in for, but I'm not frightened by the notion of institution as such. I enjoyed departmental life from the organizational demands that it makes. I am clearly very much a college person and I've enjoyed being in the institution. So that is where I think in my own life I might echo where people with religion might find some inspiration for being interested in how people arrange their social relations.

Alan MacFarlane (interviewer): Is this the same as ritual? Because a lot of (particularly Jewish) people I interviewed say that of course dogma and the intellectual side is unimportant in their lives, they are secular Jews, but the rituals gave a pattern and meaning to their lives - is that really what you're talking about, the patterning of life for Jews, symbolic elements, or is the social relations of the institution that really appeal to you, being part of a team?

\footnotetext{
$1 \quad$ I would like to thank Eirini Avramopoulou, Paolo Heywood, Ashley Lebner and the editors of this volume for their insightful comments on earlier drafts, which greatly helped clarifying and sharpening my argument.

${ }^{2}$ All italics in the interview excerpt are mine, and are meant for emphasis.
} 
Strathern: I think it has to be both, and what is ... or what I found about the ritualisation aspect (particularly in college but also elsewhere), or aspects of it, and ...- my mind slides over to bureaucracy, it starts taking ... goes off in different tangents - but if you keep to the benign rituals, like for example having a seminar at 5 o'clock on a Friday afternoon, then what I ... a particular pleasure I derive is the relationship one has to a convention, where one willingly follows a convention, but in such a way that in no way impinges on one's autonomy. In other words it's a discipline, it's a willing submission to a convention for the pleasure of the convention, but at the same time one is conscious of oneself very much, it's not as if one disappears underneath the convention but on the contrary one is an active participant. And I have always found the relationship between person and office - which is what I discuss in this contribution to Cambridge Anthropology - an actual source of intellectual pleasure, something that I enjoy managing.

[...]

MacFarlane: In a recent piece you wrote for ... I think to be published in Cambridge Anthropology, which is a reply to something I wrote, you put forward the (as usual) counterintuitive argument that there wasn't enough bureaucracy in the post of Head of Department of Social Anthropology and so on. Could you explain what you were arguing there?

Strathern: I was following a particular writer who laments the demise of old-style civil service and of the notion of a bureaucracy as a service order within government, distinct from politics. And what is being lamented is the personalization of administrators, the extent to which civil servants these days are meant to have ownership of their projects as opposed to being very much personally involved and so forth. So that what is regretted is not bureaucracy per se, but this very particular form of understanding in the Civil Service that there were procedures and principles that, as it were, saved one from the effects of too much personal investment in what was going on. One of the things I do mention there is that some of the functions of that old-style bureaucracy you find not these days in bureaucrats, but in some of the techniques they surround themselves with. So one of our problems in the current era, when we feel oppressed by what we might call bureaucracy, is not so much the activities of individuals but it is the kinds of programmes that are set up that we have to conform to. So for example the head of 
department has a constant sort of pro-forma things to be filled in, where only certain answers to questions will do because otherwise the machine throws them out or whatever. And I think this is a new - well, I shouldn't be evaluative about it I'm sure, but it's certainly a new way of dealing with process and procedure.

[...]

The University [of Cambridge] is running (well, you know!), it's running in many epochs, you know, there is a monastic culture, there is an eighteenth-century coffee-room culture, there's a corridor culture, there's a nineteenth-century entrepreneurialism, there's twentiethcentury management, and these things are all running simultaneously, and it makes it a very complex place. And that of course keeps it creative. The complexity means that there are all kinds of metaphorical corners and nooks and crannies that allow idiosyncratic procedures (or used to) to flourish.

(Interview given in 2009, part of Cambridge historian-anthropologist Alan

MacFarlane's series on 'leading thinkers') ${ }^{3}$

Strathern+Butler, via Haraway: Assembling, disassembling, reassembling cyborgs

The article cited in the interview above (Strathern, 2009), alongside this exchange itself, speak to foundational issues within queer politics, if 'counterintuitively' - in characteristic Strathernian fashion, as MacFarlane would have it. Indeed, queer as a philosophy of praxis may be seen to work at cross angles from Strathern's project, and it is with this intersection, which is also an interference, that I am concerned. I work through a feedback loop that allows to recursively play out one set of arguments against the other and thereby reconfigure them, showing how 'queer' can be both an effect and a source of some of the challenges that Strathern addresses, whilst both contain their own unresolved conflicts. Her long-standing (self-)reflections, in which the project of anthropological knowledge production stands in awkward and oblique dialogue with the concerns of feminism, Marxism and the critique of neoliberal bureaucratic power, among others, are both superseded by and incorporated into queer thinking. Yet, their encounter may produce new reverberations and ripples. In a sense, the assemblage I am about to conjure up is also anachronistic, or perhaps cannibalistic - feeding on and into its own previous parts.

Thus, articulating Strathern's reflections to queer thought means confronting what looks like a novel rehearsal of the 'awkwardness' that she herself identified between feminism and anthropology (Strathern 1987; 1988; 2004 [1991]), one that has been displaced onto new grounds. The terms of such awkward relation have changed along with the reconfigurations of institutions and disciplines themselves, as it is only natural to expect. What follows is thus an attempt to elaborate on and extend those 'partial

\footnotetext{
${ }^{3}$ Available at http://sms.cam.ac.uk/media/1130673, retrieved 19 March 2017
} 
connections' with which Marilyn Strathern (2004) productively experimented, an operation I conceive as a work of constant assembling and disassembling for the sake of making disparate elements compatible, cyborg-style, in an attempt at subversion against totalisation.

In order to proceed with this work of assemblage it is necessary to choose one's parts carefully, knowing that both scales and sides matter. As a way to 'capacitate modes of life currently around us but without an explicit force among us', this is, by definition, a risky enterprise, full of potentiality and exhaustion (Povinelli 2012, 454). I begin with two authors and their intellectual corpus - already complex and composite entities within themselves: Judith Butler and Marilyn Strathern. Yet, for this process to be accomplished it will be necessary to make partial connections also to and through the intellectual production of Donna Haraway, and particularly to the concept of cyborg as the central image of 'an ironic political myth faithful to feminism, socialism, and materialism' (1988, 149). Haraway's conceptualisation is one of the principal inspirations for what can rightfully be considered as a method as well as a position. According to Strathern, the image of Haraway's cyborg is what best renders the endeavour of partial connection-making. It is a way to extend the capacities of each part, where the latter cannot be subsumed under a coherent whole, but will always belong to different orders - and where the extension of capacities is to be understood against totalising fantasies and practices of domination, oppression and diminution.

In a sense, Butler and Strathern, like Haraway, seem to belong to the same scale and part in more than one way, as their productions have been spawned in parallel, and in some cases even in dialogue, since the dawn of 'the postplural' (Strathern 1992) and of queer (Butler 1990) on the horizon of critical reflection. They intersected and even contaminated each other in several occasions, in books and elsewhere. Strathern's work clearly contributed to the elaboration of Butler's queer thinking, most directly by unsettling the stable opposition between nature and culture which was foundational to much feminist thinking in the 1970s. ${ }^{4}$

Assembling awkward cyborgs is an explicitly queer operation, insofar as it is about transgressed boundaries, not only those between human and animal, between humananimal and machine, and between the physical and the non-physical, but indeed those between man and woman, in both their sex and gender dimensions - it is

an effort to contribute to socialist-feminist culture and theory in a postmodernist, non-naturalist mode and in the utopian tradition of imagining a world without gender, which is perhaps a world without genesis, but maybe also a world without end. [...] The cyborg is a creature in a post-gender world; it has

\footnotetext{
$4 \quad$ Butler explicitly draws on McCormack and Strathern's (1980) widely known collection in her seminal Gender Trouble (1990,37), to begin her questioning of the naturalisation of sex. This is the most obvious, even plain, way in which Strathern's anthropology (and not only hers) contributed to the elaboration of queer thinking. Much later (2016a), Butler will acknowledge Strathern's contribution to feminist theory even more extensively and explicitly. On her part, Strathern draws on Butler's thought less self-consciously, but see her intervention as chair of Judith Butler's discussion of 'Psychoanalysis and Feminism: A Radical Assessment of Freudian Psychoanalysis (Mitchell 1974)', part of 'Oppression \& Revolution: A Symposium in honour of Juliet Mitchell's retirement from the University of Cambridge' (Centre for Gender Studies, University of Cambridge, 2009). In that occasion, I recall Butler's surprised reaction to Strathern's characterisation of her thought as 'pragmatist' - perhaps a hint to that awkward relationship on which I reflect here.
} 
no truck with bisexuality, pre-oedipal symbiosis, unalienated labour, or other seductions to organic wholeness through a final appropriation of all the powers of the parts into a higher unity.

(Haraway 1988, 150 - cf. also 176, 180-1)

Yet, drawing partial connections means avoiding 'assumptions of comparability' (Strathern 2004, 38). To be assembled as a cyborg, parts need to display the characters of incomparability which define the exercise of making them compatible for a clearly partisan project (Haraway 1988). Hence, all three components in this experiment at cyborg assembling (Strathern and Butler, via Haraway) may be connected only through some radical difference, which however needs to be actively worked - after all, the connections are manifest.

This might, then, begin as another rehearsal, or a revitalisation, of the now decades-old dilemma of awkward relations. It is not really an innovative attempt but rather a contemplation of an already assembled cyborg, or meta-cyborg. However, contemplation from a situated position, and as a performative act in itself, is necessarily an addition to, or reassemblage of, the cyborg, queer style. It is a queer act, if queer can be stretched to encompass resignification of norms that do not pertain (or not only) to the domain of sexuality (as indeed Butler herself acknowledges, for example in articulating sex to race in Bodies that Matter; cf. Halley and Parker 2007; Boellstorff and Howe 2015; and Boellstorff 2010 on queer as method), and if we then take Strathern's, Haraway's and Butler's bodies of thought as ever-redeployable tools to rework 'abjection into political agency' (Butler 1993, xxv). Contemplating Strathern+Butler as a cyborg, through Haraway's conceptual device, means regenerating and extending 'them' as bodies of thought, as Haraway would have cyborgs do. Thus, of course, if we are still to identify an awkwardness, this is inevitably displaced from where it was originally spotted.

In the first place, going back to the interview with which I opened my reflections, the relation between what Strathern calls persons and their roles, which she characterises as a twentieth-century mode of discipline founded on the willing adherence to a summoning order, is addressed by Butler for what it leaves in its shadow. From queer perspectives, it is non-adherence to the norm that must be attended to, in relation to an architecture of power relations that reproduce themselves through constitutively frustrated attempts to satisfy their interpellations. In doing so, they point not only to the ways in which norms are reproduced by their negation, but also explore the potential of subversion inherent in inhabiting the law from the position of the abject. Thereby, a space is opened up in which different ways of relating can be recuperated for an insurgent politics, here and now.

In queer terms, there are no pretensions to the 'separation from an antithetical Other which [feminists] desire' (Strathern 1987, 290) - the transgressive posture which constituted the object of anthropology's mockery of feminism according to Strathern. That Other, the prohibitive paternal law, is seen to function in its very failures, in a perpetual play between repression and transgression which reproduces order. Butler's queer theory seeks to go beyond the 'singular and prohibitive' account of the Law, 'a fictive and repressive notion' (Butler 1990, $156 \mathrm{fn} .51$ ), and rather speaks to the possibility of enacting an identification that displays its very own phantasmatic structure, and therefore the radical, constitutive impossibility of the law's prohibitions and demands (Ibid., 31) - which is, at the same time, the mechanism of its reproduction. 
In this sense, there is no such thing as an 'ethical bureaucrat' in keeping to the book. Transgression, here, is the starting point rather than the end goal.

[T]he contentious practices of 'queerness' might be understood not only as an example of citational politics, but as a specific reworking of abjection into political agency that might explain why 'citationality' has contemporary political promise. The public assertion of 'queerness' enacts performativity as citationality for the purposes of resignifying the abjection of homosexuality into defiance and legitimacy. I argue that this does not have to be a 'reversediscourse' in which the defiant affirmation of queer dialectically reinstalls the version it seeks to overcome. Rather, this is the politicization of abjection in an effort to rewrite the history of the term, and to force it into a demanding resignification [...]. If there is a 'normative' dimension to this work, it consists precisely in assisting a radical resignification of the symbolic domain, deviating the citational chain toward a more possible future to expand the very meaning of what counts as a valued and valuable body in the world.

(Butler 1993, xxv-vi)

In fact, Butler sees the kernel of such an approach already at play in Strathern's early reflections on gender, published only very recently (2016 [1974]): the displacement of stereotypes through their embodiment, the phantasmatic character of role descriptions and the ensuing possibilities for mimicry and critical reflection, as well as the different forms of attachment to fantasy (Butler 2016a, 296-9). And yet, here is where some gap opens between Strathern's and Butler's thought, and thus where the cyborg-assembling work might begin.

The concept of subversion and the cognate one of transgression, whilst for the most part not directly addressed by Strathern in her analyses, may be seen to underlie many of her musings - on feminist politics inside and outside academia, and on the foundations of such thought and praxis within the dyadic matrix of individual and society. Much of Strathern's work was devoted to questioning the juxtaposition of the logic of a freedomconstraining power upon relations and dynamics - most notably those that accrue in Melanesian contexts - that seemed to follow different preoccupations entirely. By reference to a 'Melanesian' perspective on feminist-anthropological concerns, Strathern has conjured up a vision in which

gender is not construed as a role 'imposed' on individuals 'by culture'. Conversely, there is no problem about membership 'in society' or one's fitness to participate in the social contract. There is no anxiety, pace Mead, about whether or not one's attributes will qualify one for this or that role. Anxiety, so to speak, is not so much about the control of behavior (people's 'freedom') but about how their behavior will appear to others (their 'performance'). 
What is left of 'politics' from this perspective, then? Strathern shows how the language of rights attendant to (at least a certain) activism is premised on a vision of persons as self-owners and as singularly responsible for the production of, and thus entitled to, goods through their work and labour (Ibid., ch. 6; 2016 [1974]; cf. Green, 2016 on how this was the case in late-1980s feminist separatism in London). Yet, as Carol Pateman (1988) among many others reminds us, both Marxian (and in some cases Marxist) and some strands of feminist thought openly reject the view that individuals as self-owners can be foundational to a politics of liberation. The discipline of anthropology, and Strathern's work within it, has arguably contributed to forge this critique. For Pateman, however, as for many others, the solution is one of upholding limits to freedom in the name of an autonomy which is yet again predicated on the integrity of an unviolated, unitary self (attributed with binary sexual difference) that arguably still draws from individualist Enlightenment philosophy (Szörényi 2014).

Reacting against such a stance, Butler's more recent work has sought to conceptualise a radical politics based on the recognition of mutual interdependence, understood in terms of vulnerability (e.g. 2004; 2016b). For Butler, the impasse of individualism and its attendant identity politics is overcome, again also referencing Strathern's writing and thinking, if relationality as interdependence is taken as the grounding for identification (2016a, 300-2). At the same time, however, Butler's is a stance in which resistance, the play between individual freedom and social constraint, is very much at stake - as it is for queer and gender theory more generally (Povinelli 2007). To what extent, then, is her thinking incorporating, partially connecting to, the 'Melanesian' one, in Strathern's sense - and should it? And to what extent is Strathern's thinking and dealing with institutions transcending the postulates of individual, autonomous selfhood?

To put it very bluntly, we could say that whilst (part of) Strathern's work was dedicated to understand the meanings and uses of exploitation attendant to specific constructions of personhood (Melanesian - as perceived, imagined and crafted from the point of view of a 'Euro-American' anthropological discipline devoted to making partial connections), in which 'resistance' can only take interpersonal or nonhuman form, ${ }^{5}$ for Butler the main question is to re-define, in an activist sense, the meanings of resistance and selfhood. Butler's thinking is self-consciously inscribed within, and against, a specific genealogy, that of heteronormative, patriarchal, Enlightenment thought, in which exploitation is understood as a wounding violence, which appropriates and excludes. Butler's and Strathern's work thus meet at cross angles - hence the awkwardness, and the potential for partial connection. ${ }^{6}$

\footnotetext{
$5 \quad$ Strathern writes: 'As I understand Melanesian concepts of sociality, there is no indigenous supposition of a society that lies over or above or is inclusive of individual acts and unique events. There is no domain that represents a condensation of social forces controlling elements inferior or in resistance to it. The imagined problems of social existence are not those of an exteriorized set of norms, values, or rules that must be constantly propped up and sustained against realities that constantly appear to subvert them. People are subverted by the actions of other people. Or they are attacked by nonhuman forces forever beyond their reach. The world is not mapped into spheres of influence, into adjacent and competitive empires. Nor do people envision a hierarchy of levels whose final battle ground is the subduing of the human body' (Strathern 1988, 102, emphasis mine)

I see this as a way to overcome the distinction between different 'Others' which Strathern posits in her rendition of the awkward relation, which from my own vantage point do not (any longer) constitute mutually exclusive forms of subjectivation but rather can be articulated to each other. Strathern defines anthropology's 'Other' as a sort of subaltern figure, whilst feminism's own, in her rendition, is individualist, Western patriarchal law. I would say that in post-disciplinary times such
} 
Within these incompatible starting points, Butler's awkward relations with Strathern also lie in the former's reliance on a decidedly psychoanalytical account of how gender norms are internalised, which she pits against a sociological one. '[W] hereas for the latter, the internalisation of norms is assumed roughly to work, the basic premise and indeed starting point of psychoanalysis is that it does not' (Rose, cited in Butler 1990, 156, fn. 51), such that 'insurrections' against the law are somewhat to be expected. In fact, for Butler subjectivation is always and necessarily a matter of ex-centricity in relation to a symbolic order which is by definition unattainable. If 'Melanesians' can only be described as being concerned with other sorts of issues, when dealing with 'Euro-Americans' (or 'the English') Strathern is rather interested in accounting for how individuals make their relations in 'society', or indeed how they conceive of 'relatedness' and thus only obliquely, if at all, touching on the impossible relation between subject and symbolic law, and thus on the phantasmatic character of the individual. Considering this gap would amount to undertaking a work of interpretation, of reading between the lines (in considering the type of attachments of the person to the office, as it were), which is antithetical to Strathern's understanding of the task of anthropology as 'redescription' (Lebner 2017a), ${ }^{7}$ or to addressing the psychoanalytical discourse head on as cultural script which complexifies the notion of individuals and individuation by reference to desire, which simply she has not done.

Furthermore, the notion of discipline, which Strathern defines in rather specific, narrow (classical?) terms as a willing act of submission to an institution, in fact identifies a sort of anachronism, perhaps a 'postplural nostalgia' (cf. Strathern 1992, 186-98). Discipline is particularly good to think with when reflecting on the political aspects of intellectual production, as it immediately foregrounds that exertion of power through the institution, to which Strathern reveals her attachment. At the same time, 'discipline' signals the acquisition of knowledge as a tool, indexing a process of learning by following, taking on, accepting, thus pointing to the open-ended possibilities of subjectification.

Whilst of course disciplines are, like all modern social forms, inherently plural and diverse, I take the academic disciplinary order to be an instantiation of a more general form of institutional discipline. This of course has implications for anthropology in its disciplinary dimensions. Indeed, Strathern's writings often proceed by self-consciously adopting the perspective afforded by anthropology as a discipline - also granting a definite (if internally plural) positionality to feminism as its counterpart (but not homologue). On the surface, then, Strathern's insistence on disciplinary commitment is at odds with, for example, Butler's explicit invoking, in one of the founding texts of queer thought and/as praxis, of an 'interdisciplinary and postdisciplinary set of discourses in order to resist the domestication of women studies or gender studies within the academy and to radicalise the notion of feminist critique' (1990: xi). And yet, of course, this being at odds is the foundation of the awkward relationship, in Strathern's terms, for feminism there figures as necessarily internally diverse, transdisciplinary. Here I suggest some ways in which Strathern's enjoyment of institutions, her disciplinary commitment, might regenerate and extend in queer

\footnotetext{
alterities infinitely proliferate in any intellectual endeavour as opposite but complementary forms of self-defining difference.

As Deiringer and Lebner quipped, Strathern's anthropology aims 'to comparatively study how we make things known to ourselves' (2009, 3); or, in the words of Viveiros de Castro and Goldman, Strathern's is 'a perspectivist theory of description that takes as its privileged object the exchange of perspectives, which is of the same order as the relation between her discourse and that which she analyses', in a 'non-dialogic second person' $(2017,183)$.
} 
fashion, where 'queer' stands as the placeholder for a political situatedness, indeed a political challenge, within the domain of knowledge production and beyond. But I also stress the limitations of such exercise.

From the position of the subject of power, discipline entails adherence to a pattern, a model of behaviour, and thus an identification with norms of some sort, which might appear as the un-queer process par excellence. However, not only is identification (the mechanism by which institutions, rules and laws continuously shape subjects) inevitable also from Butler's perspective (e.g. 1990: 30), but if for Strathern, as she elaborates in the interview excerpt cited above, discipline is not necessarily loss of autonomy, one might imply it can in fact resist domestication in the sense Butler advocates. Indeed, in Strathern's view it is in the gap opened up, in modern institutional cultures, between person and office - as in that between different institutional cultures and their temporal stratifications - that this autonomy (and the creativity it necessarily entails) can be fostered.

This can, again, give some pause to those of us who have grown up, intellectually and politically, learning that 'the personal is political', that the public-private distinction is to be deconstructed, and that therefore there must always be at least one (and usually more) person(s) recognised as standing behind and within the office, that the (public) office cannot be fully separated from the (private) personal dimension which nurtures and re/produces it. To sustain this fiction of separateness, we learnt, was to reproduce an exploitative model founded on segregation. Moreover, a dubious sense of 'impartiality' (another political anathema) lingers in the dutifully observed gap:

The specific persona of the bureaucrat is of one who takes pride in preserving impartiality and overcoming his or her own opinions. The moral agency here involves initiative and independent judgment on the part of the incumbent, although it is an agency that has its source not in the individual but in institutionally given obligations. However, while authority comes from outside the individual, this does not mean that individuals doff and don personae at will. On the contrary, personal dedication to instituted (impersonal) purposes becomes an index of the bureaucrat's ethical habitation of his or her office.

(Strathern 2009, 132, paraphrasing du Gay)

Yet, despite her hesitation in 'being evaluative' about change, when prompted to reflect on the evolution of the university's structures Strathern laments the disappearance of the distinction between person and office. This amounts, perhaps, to the demise of discipline itself, or its displacement onto a machinic order where one has to conform to restrictive protocols (thereby re-articulating bureaucrats into cyborgs devoted to oppressive practices, one may say). In Foucauldian terms, we could tag this process as one in which individual discipline gets incorporated into, and transformed by, a governmental regime in which the managerial ethos takes prominence, in the university as elsewhere. In the era in which not only has the distinction between person and office collapsed, but where its ruins have been put to the service of new techniques of extraction, exclusion and accumulation, we must ask ourselves how to make the old feminist adage productive again, how to reclaim it from its appropriation and reversal by a neo-liberal regime which personalises the political (and the institutional), and 
thereby neutralises its radical, subversive potential. How to re-wire the political-madepersonal into a utopian queer cyborg, beyond nostalgia? How to successfully mourn the death of modern disciplines and institutions?

Despite their nostalgia, perhaps Strathern's remarks about the autonomy afforded by discipline can give us a clue. Of course there are a number of ways in which they could be qualified - by pointing out that not all rituals are 'benign', for example (which she herself admits in the interview with MacFarlane, especially in relation to the new bureaucratic regime), and that disciplines are not always (or only) about willing adherence, or by questioning willing adherence itself as guarantee of autonomy:

the bureaucratic/symbolic Institution not only reduces the subject to its mouthpiece, but also wants the subject to disavow the fact that he [ $\mathrm{sic}]$ is merely its mouthpiece and to (pretend to) act as an autonomous agent - a person with a human touch and personality, not just a faceless bureaucrat. The point, of course, is not only that such an autonomization is doubly false, since it involves a double disavowal, but also that there is no subject prior to the Institution (prior to language as the ultimate institution): subjectivity is produced as the void in the very submission of the life-substance of the Real to the Institution. [...] in an obsessional ritual, the very performance of the compulsive ritual destined to keep illicit temptation at bay becomes the source of libidinal satisfaction.

\section{(Žižek 1999, 258-61, passim)}

In this light we may ask whether, then, a post-disciplinary (governmental?) form of self-conduct might not also contain its own (kinky) pleasures and perks (cf. Butler 1997), and hold possibilities for queering. This is where our current challenge lies.

However one thinks about institutions' interpellations, though, the point is hardly weakened that 'loss of autonomy' can never be full (except of course with the demise of the self) even in the face of harsh disciplinary demands. Resistance (and/as resignification, if we wish to follow Butler's lead, not unlike Haraway's own $)^{8}$ is always a possibility, however costly and risky and however 'weak' or 'strong' it is deemed to be. ${ }^{9}$ Yet, all would agree (and this is the point of debating 'politics' in the first place)

8 In Haraway's terms, cyborg politics is also a form of writing, indeed writing is cyborgs' preeminent tool. It is about 'seizing the tools to mark the world that marked them as other [...] recoding communication and intelligence to subvert command and control' $(1988,175)$, it is 'the struggle for language and the struggle against perfect communication, against the one code that translates all meaning perfectly, the central dogma of phallogocentrism' (176).

$9 \quad$ Here authors such as Butler and Žižek famously diverge in their evaluations. For Žižek, Butler's elaboration of a 'performative reconfiguration of one's symbolic condition via its repetitive displacements' $(1999,264)$ is not as radical an act as it could get. Performative reconfiguration is 'a subversive displacement which remains within the hegemonic field and, as it were, conducts an internal guerrilla war of turning the terms of the hegemonic field against itself' (Ibid.), unlike 'a much more radical act of a thorough reconfiguration of the entire field which redefines the very conditions of socially sustained performativity' (Ibid.). However, he perhaps mistakes Butler's idea of performativity as being predicated on transgression (which, on the contrary, Butler identifies as the normal procedure for subjection, as I later show) and does not quite explain how a radical act of thorough reconfiguration would essentially differ from queer performativity qua reiterative (rather than singular), redefining 
that the self can never be reduced to the mere replication of structures over-determining her. This is an implication deriving from Butler's arguments, of which we can hear echoes in Strathern's bureaucratic pleasures and in her pointing to the 'corners, nooks and crannies' of thickly layered power structures - bearing in mind, of course, that Strathern's stance, in her own words, is rather that of

an academic, rather than activist, feminist. And that means, in the university context, that my concern is to reiterate the contributions that feminist scholarship has made in thinking about debates, especially in anthropology of course, but insisting very strongly, and it still needs to be insisted, that these are contributions to the intellectual project. But not as an activist, in the sense that I don't in fact have a particularly well thought out [political] position that would translate into university dealings, except in a sort of modest way: while in the context of making appointments and the conduct of meetings and so forth, just being aware of gender issues. But, as I think you know ... I am sensitive, but I am not terribly sensitive. It took me ages to appreciate the position [that women academics often have to occupy]. I think I've been protected as well ...

(interview with Carsten 2014, 273, emphases mine)

In the light of the first interview cited at the beginning of the chapter, these are perhaps an instantiation of Strathern's characteristic propensity to understatements. This together with her embracing of awkwardness - makes 'her' (as a public persona, but one in which the 'private', intimate dimension does clearly surface, feminist style witness the passage above) a product of her context, albeit one who has made itself queer through several contaminations and partial connections. After all, the ability and willingness to play through the gaps could be characterised as a political position, and a queer one at that. At the same time, this last passage points, I would argue, to a residual dualism (between the academic and the political) which remains partly unacknowledged in Strathern's reflections on 'awkwardness'.

Yet, leaving aside for now the fraught distinction between intellectual and activist positions (especially within feminism), the productive side of 'the law' (of institutions, of power relations and their structuring effects) is something that we can identify in both Butler's and Strathern's work (as in that of many other influential thinkers, most notably Foucault in his re-reading of Nietzsche - cf. e.g. Foucault 1978). For Butler, speaking about the specific discipline that is sexuality,

the postulation of a normative sexuality that is 'before', 'outside' or 'beyond' power is a cultural impossibility and a politically impracticable dream, one that postpones the concrete and contemporary task of rethinking subversive possibilities of sexuality and identity within the terms of power itself. This

acts. From a feminist point of view, advocating a 'strong', singular, redefining act sounds suspicious to say the least. 
critical task presumes, of course, that to operate within the matrix of power is not the same as to replicate uncritically relations of domination. It offers the possibility of a repetition of the law which is not its consolidation but its displacement.

(Butler 1990, 30)

The notion of power at work in subjection [...] appears in two incommensurable temporal modalities: first, as what is for the subject always prior, outside of itself, and operative from the start; second, as the willed effect of the subject. This second modality carries at least two sets of meanings: as the willed effect of the subject, subjection is a subordination that the subject brings on itself; yet if subjection produces a subject and a subject is the precondition of agency, then subjection is the account by which a subject becomes the guarantor of its resistance and opposition. [...] what is enacted by the subject is enabled but not finally constrained by the prior working of power. Agency exceeds the power by which it is enabled. One might say that the purposes of power are not always the purposes of agency. [...] agency is the assumption of a purpose unintended by power, one that could not have been derived logically or historically, that operates in a relation of contingency and reversal to the power that makes it possible, to which it nevertheless belongs.

(Butler 1997, 14-15, passim)

I take this to be, or suggest how it articulates with, what Marilyn Strathern refers to in her interviews and written accounts, reflecting on the roles, or offices, she held for decades within the university. It is also the premise for making of awkwardness, of cyborg-style assemblages, the principle governing thought and praxis more generally from a postplural/queer perspective. However, as anticipated, awkwardness must be located at a different place in the assemblage from where Strathern originally spotted it.

Opening up this disconnect, this awkwardness, means positing the question of activism as directly related to that of social description, in a sense - that is, it is to ask exactly how we relate to norms and their impossible requests. We might love inhabiting modern institutions, mourn their demise, work through their nooks and crannies, probe and challenge them for their managerial practices which call for a self-defeating transparency. Indeed, despite Strathern's shying away from activist subjectivity, there is of course an 'active' dimension to intellectual critique, including her own - words do things, as Butler is keen to remind us, and as many scholars and their writings have repeatedly proven through the centuries. In her own (characteristically modest) words, 
Strathern conceives of her posture as 'from time to time challenging conventional ways of thinking'. ${ }^{10}$

Indeed, recent engagements with Strathern's analytical strategies are beginning to address the latter's political dimension in relation to critical redescription. They note the political implications of her reflections despite an apparent absence of specific references to politics as such, which is related to the deep embeddedness of such term within a specific intellectual tradition which Strathern seeks to de-centre and challenge (Lebner 2017a; 2017b). However, by directly engaging feminist thought, as well as Marxism (and the interlacing of the two), in her re-description of exploitation, of inequality and of exchange, most notably, but also in accounting for the workings of institutional-managerial cultures, Strathern arguably positions her work firmly at the centre of political debate, in a much more evident, if lateral, fashion than many accounts of her work are ready to acknowledge.

Which discipline? Awkward politics, militant politics, anthro-politics

Embarking in this reiterative experiment of cyborg assembling, I am of course making claims and taking my partial sides, both towards these domains of knowledge production, agentive in themselves, and in a wider sense. I am writing from a position in which not only have institutions in their modern(ist) form disaggregated (and then reassembled), to the point where we have been hearing of 'the university in ruins' for decades (Readings, 1997), but where one's attachment to such 'debris' is ever more precarious, let alone desirable or indeed pleasurable. This may be so for all concerned, but certainly demands, expectations and rewards are unequally distributed, and require 'a concern for the future already among us - a future that a kind of curiosity mixed with a kind of willfulness one could pull out of the present' (Povinelli 2012, 453).

In this conjuncture, the 'metaphorical nooks and crannies' evoked by Strathern in her interview with Alan MacFarlane may no longer be productive gaps but all there is left of the old institution. In overly complex, ruined structures, therefore, idiosyncratic procedures are no longer granted any more than is the internally plural structure itself - something to which Strathern seems to hint with nostalgia. It goes without saying that what has risen out of the debris, perhaps feeding off the process of its ruination, is a powerful organisation - but one of a different, postplural nature, in which differences may be seen to proliferate only at the expense of their neutralisation. There is now wide consensus, among both academics and the general public, that the neoliberal university has progressively ceased to function as a distinct kind of institution to take the form of a corporation, where creativity and complexity are erased in the process of their valorisation and where scholars are increasingly turned into managers. Indeed, Strathern's reflections on the subject (most famously her Audit Cultures edited collection, 2000) were crucial to illuminate aspects of this process. The question, then, turns to what the place and nature of discipline might be in such context.

Thus, whilst taking inspiration and starting from her reflections on knowledge, the university and a number of other issues, my partial connections are obviously taking me to rather different directions to those trodden by Strathern. To speak of 'queer' from the point of view of academic discipline(s), of those institutions which are close to home for (or better, are indeed home to) all the parts in the assemblage I engage with, seems

\footnotetext{
10 'Inside the President's Studio - Marilyn Strathern', interview with Virginia Dominguez, March 2011. Available online at https://blog.americananthro.org/2011/03/31/inside-thepresidents-studio-marilyn-strathern/, retrieved 10 June 2017.
} 
like a good way to reflect on politics from a perspective (one which owes much to feminist thought and critique) in which the private, intimate, personal, on the one hand, and the public, on the other, are themselves intimately intertwined. As Boellstorff has noted with specific reference to anthropology as an academic discipline, and to the anthropology of gender and sexuality in particular (2007: 18-19), its institutional context has been central to the development of queer studies, as the vector making certain kinds of approaches possible, indeed creating 'homes' for their scholars - thus mutually imbricating subject and object, figure and ground. Echoes of Strathern's thinking surface here.

And yet, insofar as it is on the inescapably political qualities of queer within the ruination of university that I wish to focus my attention - on queer as a method and guide for change, and thus on the ever-fraught relationship between knowledge production and transformative action - I am departing from Strathern's own language, if not from her concerns. From this angle, I am facing an unease which the contemporary university as an institution built on ruins makes particularly stark in many ways. Indeed, while a disciplined institutionalisation of queer projects may be undesirable and unattainable, or at best anachronistic, for the purposes of radical politics, in the current academic context it is their very recognition, indeed their radical effect, that is at stake (cf. Borghi, Bourcier and Preiur 2016; Boyce, Engebretsen and Posocco 2017). More often than not, the institution acts to neutralise and appropriate such projects, or even to erase them. The challenge is thus that of assembling a subversive tool that can help us configure more just forms of knowledge-production and relations. Perhaps we need to renew our disciplines, once again, in order to pursue this project.

This is what remains partially hidden in Strathern's reflection on the incomparability between feminism and anthropology: the militant nature of the feminist project, the fact that it is not, in the first instance, a purely intellectual endeavour (unlike anthropology, at least in its canonical self-representations). This is the fundamental awkwardness that drives cyborg assembling - after all, cyborgs are eminently 'political' creatures in Haraway's intentions, but being cyborgs they extend and remake the meanings of such politics (whilst, in Haraway's words, remaining faithful to feminism, socialism and materialism). The challenge, then, after having considered feminism's theoretical stance and implications, seems to be to come to terms with the political dimension of anthropology. What is more, it is perhaps in militancy that a sense of discipline can be recuperated, beyond modern institutions and as a way to create partial connections between scholarship and the domains it reflects on and describes. If Strathern identified a disconnect between radical politics and radical scholarship (1988: 27), the current conjuncture seems favourable for a re-articulation in which the one need not be conceptually conservative, or the other politically so. And this is thanks also to the work of feminist scholars such as Strathern and Butler, who have taught us how to be radical without assuming identity in its strong ontological sense.

Of course this means constant conceptual alertness and redefinition - the point of queer performativity. It is discipline in its ethical sense, but one which challenges oneself and the institution to cast both off and regenerate them (Povinelli 2012). Another thing is to have a 'well-thought out political position that translates into university dealings' - but then again, how definitive would we want this position to be anyways? Is it not more a matter of tactical subversions and alliances (echoes of lessons learned from distant lands and colonial settings?), of constantly reworking our politics from the point of view of relations? This is what one might read in-between the lines of Strathern's posture within the institution: 
I knew right from the outset in Manchester that the one thing you need to prevent is a cleavage; you can have any number of prima donnas, alliances, whatever, but as long as the alliances keep on cross-cutting with one another, and different issues engage different constellations of interests, everything is fine. As soon as you have a cleavage in a department, a crevasse, then every issue falls into it; this worked in Manchester, it had to be worked at in the Cambridge department, but is really true of Girton, that although from time to time the Fellows divide themselves, and although they have to always overcome some arts-science divide, simply because of the different kinds of demands of the University, I think I can fairly say there are no divisions that have split the community.

(Interview with Alan MacFarlane, 2009)

Yet the activist, queer posture is not simply a realisation of the impossibilities of adhering to the law: it is a deliberate reclaiming of this gap, of acting conflict out whereas the role of 'head' rather implies acting to re-compose the gap, overcome it. This of course can be done in a number of ways, and carries itself an activist dimension: to be able to detect exclusion and abjection (of women for example), and to recognise its political agency, is what makes for a queer 'head'. And the reclaiming (as much as the re-composition perhaps) is, as noted in the beginning, propped up by analyses, ideas, elaborations which may include those on 'Melanesian' ways, knowing that things can be done differently, that laws need not be carved in stone and that contamination, or partial connection, is a possibility, indeed a political necessity. In this sense, paraphrasing a well-known author, if 'Margaret Mead made us gay' (Newton 2000), 'Marilyn Strathern made us queer', both in her unsettling the grounds of gender identities and thereby also questioning the forms of militant politics that we deploy to contrast such strong forms of identification. Of course 'Melanesians' are a word doing things here, a shorthand for relationality as constitutive of selves, perhaps, in the awareness that what we are facing is a postplural world in which even the symbolic/institutional order might be in question and where, therefore, 'queer' might be defused in its subversive capacities and put to work for a regime of boundless consumerist enjoyment. Indeed, it is only by assuming our own vulnerability, deliberately assuming risk and exhausting ourselves, and recognising the violence and vulnerability endured by others, by those we work with, that we can turn discipline(s), including anthropology, into transformative projects. Queer, indeed, can only exist only as one of the names of this embodied, lived vulnerabilities and pains, lest it betrays itself.

But to demand of 'heads', institutional figures par excellence, in all their radicalness (a radicalness that Strathern and Butler both expressed in very different guises, at least 'intellectually' as Strathern would put it), to 'queer' knowledge or the institution is perhaps to miss a point. Their cyborg assemblage can only serve as a weapon in the hands of, and for, the abjects - the precarious, the non-subjects of neo-liberal institutions. It is from that position, and only from that, that subversion can proceed, however it is then dealt with by institutions and their heads, who might or not accept the challenge of recognising and owning their own precarity. But however institutions, or their ruins, react, that should be no reason to interrupt our efforts. 
References

Boellstorff, T. (2007). Queer Studies in the House of Anthropology. Annual Review of Anthropology 36, 17-35.

Boellstorff, T. (2010). Queer Techne: Two Theses on Methodology and Queer Studies. In K. Browne and C. Nash, eds., Queer Methods and Methodologies: Intersecting Queer Theories and Social Science Research. London: Ashgate.

Boellstorff, T. and C. Howe (2015). "Queer Futures.” Theorizing the Contemporary, Cultural Anthropology https://culanth.org/fieldsights/709-queer-futures

Borghi, R., M. Bourcier and C. Prieur (2016). Performing Academy: Feedback and Diffusion Strategies for Queer Scholactivists in France. In G. Brown and K. Browne, The Routledge Research Companion to Geographies of Sex and Sexualities. London: Routledge.

Boyce, P., E. Engebretsen, and S. Posocco (2017). Introduction: Anthropology's Queer Sensibilities. Sexualities:1-10.

Butler, J. (1990). Gender trouble: Feminism and the subversion of identity. New York: Routledge.

Butler, J. (1993). Bodies that matter: On the discursive limits of 'sex'. London and New York: Routledge.

Butler, J. (1997). The psychic life of power: Theories in subjection. Stanford, California: Stanford University Press

Butler, J. (2004). Undoing gender. New York and London: Routledge.

Butler, J. (2016a). Afterword. In M. Strathern, Before and after gender: Sexual mythologies of everyday life. Chicago: HAU Books.

Butler, J. (2016b). Rethinking vulnerability in resistance. In J. Butler, Z. Gambetti and L. Sabsay, eds., Vulnerability in resistance. Durham and London: Duke University Press.

Carsten, J. (2014). An interview with Marilyn Strathern: Kinship and career. Theory, Culture \& Society, 31(2-3), 263-281.

Foucault, M. (1978). The history of sexuality, Vol. I: An introduction. New York: Pantheon Books.

Green, S. (2016). Located in between times. HAU: Journal of Ethnographic Theory, 6(3), 387-391.

Halley, J. \& A. Parker (eds.) 2007. After sex? On writing since queer theory. South Atlantic Quarterly special issue 106(3), 421-646.

Haraway, D. (1988). A cyborg manifesto: Science, technology, and socialist-feminism in the late twentieth century. In Simians, cyborgs, and women: The reinvention of nature, pp. 149-181. New York: Routledge. 
Lebner, A. (2017a). Introduction: Strathern's Redescription of Anthropology. In A. Lebner (ed.). Redescribing Relations: Strathernian Conversations on Ethnography, Knowledge and Politics, pp. 1-37. Oxford: Berghahn Books.

Lebner, A. (ed.) (2017b). Redescribing Relations: Strathernian Conversations on Ethnography, Knowledge and Politics. Oxford: Berghahn Books.

Lebner, A. and S. Deiringer (2009). Editors' Note. Special Issue of Cambridge Anthropology: The William Wyse Professorship, the Organisation of Knowledge and the Work of Marilyn Strathern 28(3), pp. 1-6.

McCormack, C. and Strathern, M., eds. (1980). Nature, culture and gender. Cambridge: Cambridge University Press.

Newton, E. (2000). Margaret Mead made me gay: Personal essays, public ideas. Durham: Duke University Press.

Pateman, C. (1988). The sexual contract. Stanford: Stanford University Press.

Povinelli, E. (2007). Disturbing sexuality. The South Atlantic Quarterly 106(3): 565576.

Povinelli, E. (2012). The Will to Be Otherwise/The Effort of Endurance. The South Atlantic Quarterly 111(3): 453-475.

Readings, B. (1997). The university in ruins. Cambridge, MA, and London, England: Harvard University Press.

Strathern, M. (1987). An awkward relation: The case of feminism and anthropology. Signs, 12(2), 276-292.

Strathern, M. (1988). The gender of the gift: Problems with women and problems with society in Melanesia. Berkeley: University of California Press.

Strathern, M. (1992). After nature: English kinship in the late twentieth century. Cambridge: Cambridge University Press.

Strathern, M., ed. (2000). Audit Cultures: Anthropological Studies in Accountability, Ethics and the Academy. London: Routledge.

Strathern, M. (2004 [1991]). Partial Connections. Updated Ed. Lanham: Altamira Press.

Strathern, M. (2009). Afterword: The disappearing of an office. Cambridge Anthropology, 28(3), 127-138, Special Issue: Bureaucratic knowledge practices, the William Wyse Professorship and the work of Marilyn Strathern. Guest editors: Sabine Deiringer and Ashley Lebner.

Strathern, M. (2016 [1974]). Before and after gender: Sexual mythologies of everyday life. Edited and with an introduction by Sarah Franklin. Afterword by Judith Butler. Chicago: HAU Books. 
Szörényi, A. (2014). Rethinking the boundaries: Towards a Butlerian ethics of vulnerability in sex-trafficking debates. Feminist review, 107, 20-36.

Viveiros de Castro, E. and M. Goldman (2017). Slow Motions [Extended Remix]: Comments on a Few Texts by Marilyn Strathern. In A. Lebner (ed.). Redescribing Relations: Strathernian Conversations on Ethnography, Knowledge and Politics, pp. 173-196. Oxford: Berghahn Books.

Žižek, S. (1999). The ticklish subject: The absent centre of political ontology. London, New York: Verso. 